\title{
SISTEMAS AGROFLORESTAIS PECUÁRIOS COM ÊNFASE NAS ESPÉCIES FRUTÍFERAS ARBÓREAS E ARBUSTIVAS
}

\author{
Tatiane Pereira Guimarães ${ }^{1}$; Rosana Quaresma Maneschy² \\ ${ }^{1}$ Discente do curso de Agronomia, Faculdade de Ciências Agrárias de Marabá (FCAM), Universidade Federal do Pará \\ (UFPA), Marabá, Pará. Bolsista FAPESPA. E-mail: tatianepg.ufpa@gmail.com. \\ ${ }^{2}$ Engenheira Agrônoma, Prof., , D.Sc., FCAM, UFPA. E-mail: romaneschy@ufpa.br.
}

RESUMO: Tradicionalmente os agroecossistemas de pastagem são monoculturas sem a utilização do componente arbóreo associado. A adoção de espécies frutíferas em SAFP contribui para viabilizar a permanência do agricultor em uma mesma área, colaborar com a segurança alimentar, gerar ingressos adicionais de renda, maximizar a produtividade por unidade, propiciar o aumento da biodiversidade, otimizar a absorção de nutrientes e água, recuperar áreas degradadas e/ou abandonadas para que seja possível alcançar sustentabilidade nessas unidades de produção familiar. Este trabalho tem como objetivo difundir os SAFP com ênfase nas espécies arbóreas e/ou arbustivas frutíferas, no contexto da agricultura familiar da região de Marabá no estado do Pará e será desenvolvido no Projeto de Assentamento (P. A.) Belo Horizonte I, no município de São Domingos do Araguaia, na microrregião de Marabá. A pesquisa será realizada no âmbito do projeto "Sistemas silvipastoris e agrossilvipastoris como alternativa para a sustentabilidade da pecuária na agricultura familiar da região de Marabá - PA" desenvolvido pela Universidade Federal do Pará - Campus de Marabá com apoio financeiro da FAPESPA. A abordagem do projeto se enquadra nas metodologias de pesquisa-ação e de pesquisa participativa. A metodologia prevê a construção da parceria e tomada de decisão das ações prioritárias do projeto em três fases. A primeira fase consiste na realização de reunião para apresentação do projeto e de diagnóstico com os agricultores interessados em desenvolver ações-testes envolvendo o componente arbóreo. O diagnóstico será realizado realizados através de visitas aos lotes e entrevistas estruturadas, com auxílio de um questionário com perguntas abertas e fechadas e os dados serão analisados através de estatística descritiva. A segunda fase será de sensibilização, para que a comunidade priorize a inserção do componente arbóreo na paisagem rural. Para isso serão realizadas atividades utilizando os recursos pedagógicos propostos na Mochila do Educador Agroflorestal elaboradas pelo Projeto Arboreto da Universidade Federal do Acre. A terceira fase será de intervenção, com a realização de cursos (coleta de sementes, quebra de dormência de sementes, minhocultura e vermicompostagem, produção de mudas), elaboração dos planos de implementação de cada ação-teste, implantação e acompanhamento dessas ações, de forma conjunta auxiliando no processo de construção de inovações no PA. Serão realizadas reuniões de avaliações das atividades e nessa ocasião será aplicada a técnica de Diagnóstico Rápido Participativo para analisar o conhecimento adquirido da comunidade a partir das atividades desenvolvidas nessa ação. Também será realizado o acompanhamento do desenvolvimento inicial das mudas no campo. As plantas serão avaliadas quanto a: sobrevivência, altura total $(\mathrm{m})$ e diâmetro do coleto $(\mathrm{cm})$ mensalmente durante um ano. A partir de $1,50 \mathrm{~m}$ de altura serão avaliadas diâmetro a altura do peito - DAP $(\mathrm{cm})$ e diâmetro de copa - DC (m). Espera-se contribuir com a difusão dos sistemas agroflorestais pecuários com ênfase nas espécies arbóreas e/ou arbustivas frutíferas para a recuperação de áreas de pastagens degradadas, pois a adoção dos mesmos pode agregar valor ambiental e econômico as atividades produtivas já desenvolvidas, e ao mesmo tempo, atender à legislação ambiental, configurada principalmente na recuperação de Área de Preservação Permanente (APP) e Reserva Legal (RL).

PALAVRAS CHAVES: Agricultura familiar, integração árvore-pastagem, integração culturaárvore-pastagem. 